\title{
DIMENSI TASAWUF DALAM PUISI ACEP ZAMZAM NOOR
}

\author{
Bunyamin Faisal S \\ Mahasiswa Pascasarjana S-3 Universitas Padjadjaran
}

\begin{abstract}
Abstrak
Puisi adalah ruang ekspresi dalam bentuk bahasa bagi seorang penyair. Ruang ekspresi itu merupakan tahapan kreativitas atau proses penyair dalam menjalani perjalanan spiritualitas. Di sini puisi menjadi ruang religius penyair yang berpotensi pada tindak berpengalaman dalam keterhubungan dirinya dengan Tuhan. Pada dunia Islam istilah 'keterhubungan' dengan Tuhan ini sering disebut dengan tasawuf atau jalan kerohanian. Berdasarkan paparan tersebut pada tulisan ini membahas dimensi tasawuf dalam puisi Acep Zamzam Noor. Pada puisi Acep Zamzam Noor terdapat perkembangan dimensi tasawuf yang signifikan. Dari perkembangan periode antologinya dari tahun ke tahun mengalami perkembangan yang unik terutama pada periode awal kepenulisannya. Selanjutnya secara konsep tasawuf pun, jika ditinjau dari perkembangan eksplorasi bahasanya puisi Acep Zamzam Noor mengalami fase-fase yang berbeda.
\end{abstract}

\section{Kata kunci: tasawuf, puisi, religiusitas, metafora.}

\section{Latar Belakang Masalah}

Pada awal mula segala sastra adalah religius. Y.B. Mangunwijaya (1988: 11) mengartikan istilah religius tersebut ke dalam bentuk proses perjalanan manusia terhadap spiritualitasnya yakni manusia yang berhati nurani serius, saleh, teliti dalam pertimbangan batin dan sebagainya. Jadi belum menyebut, dia menganut agama mana. Dengan demikian asumsi dasar sastra religius berarti karya sastra yang berpotensi pada tindak berpengalaman dalam menyatukan dirinya pada Tuhan.

Karya sastra religius merupakan sebuah refleksi tentang dunia secara makro-alam, manusia, bahkan dunia transenden-melintang melingkupi suatu konsep paradigma pemikiran yang begitu baik. Sedangkan sastra dalam lingkup yang lain, dalam ruang lingkup mikro berbicara tentang dunia persoalan-persoalan manusia yakni dunia tentang pola pikir, nilai-nilai dan kreativitas. Sastra juga secara umum merupakan pola pengembangan fungsi kreativitas manusia, dan jika berbicara mengenai konsep religiusitas, sastra menjadi sarana dan fungsi ritual atau tuntunan.

Dalam khazanah keislaman, sastra religius disebut dengan istilah sastra tasawuf. Abdul Hadi W.M dalam catatan kuliahnya mengenai sastra Islam menjelaskan bahwa tasawuf ialah bentuk spiritualitas atau jalan kerohanian dalam Islam. Sebagai bentuk spiritualitas atau ajaran kerohanian, tasawuf mulai muncul dalam sejarah Islam pada awal abad ke$2 \mathrm{H}$ atau 8 M. Orang yang mengamalkan tasawuf disebut sufi. Karena itu dalam bahasa Inggris, tasawuf juga disebut sufism (sufisme). Disebabkan dekatnya dan kemiripan antara pegalaman kesufian yang bersifat mistikal dengan pengalaman estetik seniman, tidak mengherankan jika sejak awal telah banyak sufi melibatkan diri dalam kegiatan sastra, terutama puisi. Ini karena puisi merupakan penuturan 
simbolik, yang cara penyampaiannya berbeda dengan bahasa keilmuan dan falsafah.

$\begin{array}{ccc}\text { Lebih } & \text { lanjut } & \text { Abdul Hadi } \\ \text { memaparkan } & \text { pula } & \text { bagaimana }\end{array}$
pentingnya peranan tradisi puisi dalam khazanah tasawuf. Peranan penting puisi dalam kehidupan sufi berakar dalam upacara sama'(audisi). Secara harafiah kata sama' berarti mendengarkan puisi dan musik bersama-sama. Dalam perkembangannya sama' menjelma sebagai konser musik kerohanian yang disertai tari-tarian, nyanyian dan pembacaan puisi. Melalui alunan musik dan puisi yang dibacakan perasaan mereka begelora, melaluinya pula pengalaman religius mereka meningkat, oleh sebab pengalaman keagamaan berkaitan dengan sesuatu yang sifatnya kerohanian dan transendental, dan sesuatu yang rohaniah hanya bisa dicerap secara intuitif (dharuri) dan perasaan.

Puisi sufistik di Indonesia, berkembang pada masa awal perkembangan sastra seiring dengan masuknya agama Islam. Sastra (bahasa) sudah sejak abad ke-19 berkembang di Indonesia, perkembangan sastra pada waktu itu kebanyakan berbahasa Melayu. Karya-karya sastra Melayu lebih berkembang pengarangpengarangnya dari lingkungan ulama dan kesultanan di kepulauan Riau. Di antara yang paling termashur ialah Hamzah Fansuri, Raja Ali Hadji, Nooruddin Ar-Raniri, Tun Sri Lanang, dan lain-lain. Nama-nama tersebut merupakan maestro-maestro terkemuka dalam bidang kesusastraan terutama karya-karyanya yang merupakan karyakarya yang bertemakan tentang nilainilai kehidupan dan keagamaan (sufisme).

$\begin{array}{rrr}\text { Sebagai } & \text { bahan } & \text { untuk } \\ \text { menunjukkan } & \text { bahwa } & \text { permulaan }\end{array}$

kesusastraan Indonesia (Melayu) termasuk ke dalam ranah karya-karya tasawuf bisa dilihat pada karya Hamzah Fansuri misalnya. Ia sebagai seorang sastrawan besar Indonesia yang tergolong karya-karyanya bersifat Sufistik, menggambarkan sikap keterhubungan antara manusia dengan Khalik sebagaimana dalam syair Anggur bait pertama;

Syurbat mulia dari tangan Khalik

Akan minuman sekalian asyik,

Barang meminum dia menjadi natik,

Mengatakan 'Ana'l-Hakk' terlalu sadik.

Dalam perkembangan puisi Indonesia modern selanjutnya, tema religiusitas banyak juga ditulis oleh penyair-penyair modern. Sebagaimana Abdul Hadi W.M. menyebutkan dalam tulisannya Sastra Sufi Melayu dan Gemanya Dalam Sastra Modern Indonesia bahwa;

"Sastra Sufi merupakan bagian penting dari keseluruhan khazanah intelektual Islam, baik di Dunia Arab, Persia, Melayu Nusantara dan lain-lain. Ia juga merupakan salah satu dari warisan peradaban Islam yang relevan dan diminati hingga sekarang. Namun selama beberapa puluh tahun, khususnya di Indonesia, khazanahnya yang kaya itu telah diabaikan oleh kaum terpelajar Muslim dan jarang dijadikan bahan kajian oleh sarjana-sarjana sastra. Akan tetapi bersamaan dengan tumbuhnya kembali minat terhadap tasawuf dewasa ini, tumbuh pula minat untuk meneliti teks-teks tasawuf dan wacana sastra sufi di Asia maupun Eropa serta Amerika. Sebelumnya, selama lebih kurang tiga dasawarsa (sejak 1970an) telah muncul kecenderungan sufistik atau kesufian dalam penulisan karya sastra. Ini tampak misalnya dalam karya penulis terkemuka seperti 
Danarto, Kuntowijoyo, Sutardji Calzoum Bachri, Taufiq Ismail, Hamid Jabbar, Emha Ainunnadjib, Ahmadun Y Herfanda, Jamal D. Rahman, Ajamuddin Tifani, Juftazani, Acep Zamzam Noor, dan banyak lagi penulis yang lain."

Pada dasawarsa 1970-an inilah berdasarkan dari khazanah kesusastraan Indonesia dan merujuk pada catatan Abdul Hadi W.M. di atas, muncullah nama penyair modern yakni Acep Zamzam Noor (selanjutnya AZN). Dia dikatakan sebagai salah seorang penyair dengan karya-karya puisi religius.

Pada masa awal penulisan puisinya AZN dalam antologi pertamanya "Tamparlah Mukaku" ditulis cenderung pada kekuatan konsep keTuhanan yang kuat yakni tentang perjalanan kerinduan-kerinduan terhadap Tuhan.

Dari titik tolak itulah, tulisan ini akan memfokuskan pada periode awal kepenulisan AZN dalam menulis puisi dan yang menjadi kajian penelitian ini adalah menafsir ranah metafor dan kecenderungan isi dalam konteks dimensi dan perkembangan tasawuf.

\section{Analisis}

\subsection{Bahasa Metafor}

Pada periode 80-an adalah periode awal AZN membukukan puisipuisinya. Ada sekitar tiga antologi puisi pada periode 80 -an ini yakni: antologi pertamanya adalah "Tamparlah Mukaku" yang terbit pada tahun 1982, berisi 50 puisi, Empat tahun kemudian pada tahun 1986 menerbitkan kumpulan antologi keduanya yang berjudul "Aku Kini Doa", yang terdiri dari 37 puisi dan "Kasidah Sunyi" yang terbit pada tahun 1989 yang berisi puisi-puisi penggabungan dari dua antologi sebelumnya. Dalam pembahasan periode 80-an ini hanya dua antologi yang akan dibahas adalah: "Tamparlah Mukaku” dan “Aku Kini Doa”.
Secara keseluruhan, puisi-puisi yang termaktub merupakan hasil kontemplasi AZN yang sangat menawan. Jika disebut dengan tema keTuhanan, Tamparlah Mukaku memang sesuai dengan khazanah dimensi tasawuf. Jika ditinjau dari perkembangan puisi AZN secara umum, bahasa metafora yang dikembangkan dalam puisi-puisinya sebagai langkah awal dari proses kreativitasnya, AZN masih mengembangkan bentuk metafora yang berkembang pada puisipuisi sufistik Timur Tengah.

Dalam puisi yang berjudul "Lagu Yang Sederhana" misalnya:

Inilah lagu yang sederhana

UntukMu

Denting-denting rawan

Jiwa yang melayang-layang

Inilah nada-nada guram

Kasih yang terpendam

Lirik-lirik lebam

Kehidupan yang bergoyanggoyang

Matahari hanya kupandang saja Sambil menimbang-nimbang MataMukah yang memandangku Yang sejuk mengelus dan membakar sekaligus?

Sadar harus berdiri Meskipun kaki selalu goyah Sadar harus menyanyi Walau tak mampu meredakan gelisah

Inilah nyanyianku

Lagu yang sederhana

Denting-denting kerinduan

Dari harpa jiwa yang teramat lengang

1981

Puisi ini jika dibaca secara umum, sedang menggambarkan perasaan aku lirik melalui lagu untuk 
Kekasihnya. Kekasih dalam konteks ini adalah Tuhan, dengan lagu-lagu yang sederhana. Kata "sederhana" belum berarti sesederhana yang kita ucapkan, namun AZN sadar bahwa dirinya adalah manusia biasa yang tidak bisa mengungkapkan kerinduannya dengan sesuatu hal yang sangat besar. Sehingga AZN menulis dengan kesederhanaannya bahwa, Inilah lagu yang sederhana/UntukMu/Denting-denting rawan/Jiwa yang melayang-layang.

Pada posisi ini, aku lirik merasa tidak punya apa-apa, dalam setiap ungkapan yang ditulisnya selalu "rawan" dan "melayang-layang". Aku lirik sedang mengungkapkan rasa yang selama ini terpendam sehingga liriklirik yang ditulisnya selalu lebam. Permainan suasana pun pada akhirnya terus dirasakan muram, namun tetap pada posisi sadar.

Sadar harus berdiri

Meskipun kaki selalu goyah

Sadar harus bernyanyi

Walau tak mampu meredakan gelisah

Selanjutnya jika dilihat dari struktur bahasa yang dipakai dalam puisi di atas, bentuk metafora yang dimunculkan dalam puisi ini adalah "Dari harpa jiwa yang teramat lengan". Sebagaimana bahwa metafora adalah bentuk pengandaian sesuatu dengan bahasa atau ungkapan lain, maka kata harpa yang disandingkan dengan jiwa menjadi sesuatu hal yang tidak biasanya. Harpa secara harfiah adalah alat musik yang berdawai, dimainkan dengan cara dipetik lalu menimbulkan bunyi mendayu yang beragam. Namun ketika disandingkan dengan jiwa menjadi bukan harpa yang sesungguhnnya.

Ada kemenarikan tersendiri dalam penggunaan metafora ini, harpa yang disandingkan dengan jiwa tersebut secara denotasi seharusnya menjadi sesuatu yang mengisi jiwanya. Namun di sini lain, justru menjadi sesuatu yang "lengang". Rupanya AZN pada titik ini sedang memainkan kerinduankerinduan terhadap pencarian terhadap Tuhan dengan lagu yang sederhana/denting-denting kerinduan. Denting-denting harpa dijadikan suasana perasaan yang teriris juga.

Dengan demikian harpa dalam puisi ini dijadikannya alat untuk mengalunkan lagu kerinduannya yang bisa menyampaikan rasa kegelisahannya, kemuramannya, dari seluruh pengembaraan yang telah dilalui oleh si pengembara.

Selanjutnya dalam puisi "Nyanyian", AZN menawarkan juga sikap kerinduannya dengan gaya bahasa metafora yang menawan. Sebagaimana pada puisi "Lagu Sederhana", pada puisi "Nyanyian" pun menggunakan gaya metafora yang musikal. Penggunaan diksi alat musik yang digunakan dalam puisi ini menjadi semacam alat juga untuk mengungkapkan rasa resah yang sangat mendalam. Jika puisi di atas menggunakan metafora harpa, di sini AZN menggunakan diksi gitar.

Aku siap

Melayani hidup ini

Asalkan Engkau bantu

Terima-kasih, Tuhan

Bahwa aku masih bisa mengingatMu

Biarpun kelu

Untuk bernyanyi dengan merdu

Tapi ini jemari

Belum bosan memetik dawai gitar

Yang Engkau sodorkan kepadaku

Dan dengan suara parau

Aku mencoba mendendangkan kehidupan

Aku juga siap

Menjalani mati nanti 
Tapi beri aku waktu berbenah diri

Terima-kasih, Tuhan

Bahwa aku masih bisa bersujud di kakiMu

1980

Gambaran puisi "nyanyian", persis sama dengan puisi yang pertama. Bercerita tentang subjek yang selalu dirundung rindu terhadap Tuhan, dengan nyanyian-nyanyian dan kesadaran rasa terima kasih terhadap apa yang telah diberikan Tuhan. Diri subjek dalam puisi ini selalu digambarkan sebagai sosok yang sadar terima kasih bawa dirinya masih bisa "mengingat-Nya", dan bisa bersujud di "kaki-Nya".

Sebagaimana dikatakan di atas pula, tradisi kepenulisan AZN masih terpengaruh oleh karya-karya puisi sufi Timur Tengah. Pada puisi ini gaya metafora untuk mengungkapkan kerinduannya, AZN menggunakan diksi gitar. Dalam tradisi sufi penggunaan alat musik selalu dijadikan alat ritual dalam pencapaian dimensi unitas terhadap Tuhan. Namun, di sini AZN menyandingkan gitar tidak lagi-lagi dengan keresahan yang mendalam. Meski belum bosan untuk memetik gitar, namun ia tetap bernyanyi dengan suara parau.

Fungsi penggunaan metafora gitar, pada posisi ini masih menunjukkan sikap AZN bahwa sebagai manusia yang kecil yang tidak berarti apa-apa dihadapan-Nya. Kesadaran akan kebesaran-Nya membuat dendangan nyanyiannya parau - terbatabata meskipun dawai gitar selalu terus dipetik tak bosan-bosannya.

Jika pada kedua puisi di atas AZN sedang membicarakan kerinduan yang masih mengambang dengan kesederhanaan dan keparauannya, berbeda halnya dengan puisi selanjutnya yang berjudul "Keluh".
Dari dasar jurang

Kupandang Cakrawala

Beta jauh!

Ini hati sungsang

Kusandang seharian

Betapa keluh!

II

Dari kegelapan

Tak bisa kupandang apa dan siapa

Selain selaput mataku

Dan dari balik itu

Kukagumi kebesaranMu

Betapa terbatasnya aku

Betapa terbatasnya waktu

III

Dari keterbatasan

Jarak semakin mendekatkanku

kepadaMu

1981

Penggambaran batin yang
disuguhkan dalam "Keluh" ini, merupakan proses lanjutan dari apa yang dijelaskan sebelumnya. Di sini, subjek sudah merasa dekat dengan pencariannya. Pada kalimat selain selaput mataku/dan dari balik itu/kukagumi kebesaranmu. Metafora yang digunakan AZN sangat intens dan cerdas, selaput mata dijadikan gaya metafora yang dalam. AZN menuju pada yang inti, selaput mata adalah inti dari mata yaitu retina yang dengan apik dia menulis "dari balik itu" dia menemukan yang dicarinya. Sementara menjadi paradoks ketika Cakrawala yang dipandangnya betapa jauh dia rasakan. Suasana menjadi sungsang seharian betapa keluh.

Kesadaran-kesadaran sebagai manusia yang kecil diungkapkan juga di sini, yakni pada bait akhir AZN tetap menulis dari keterbatasan/jarak semakin mendekatkanku/kepadaMu. Frasa "Keterbatasan" menunjukkan 
sikap yang tidak arogan dan penuh kesederhanaan dalam peristiwa penyatuan ini.

Sebagai manusia tentu berbagai pertanyaan akan selalu berada dalam wilayah kesadarannya alih-alih pada ruang pengembaran dan pencarian yang sedang dihadapinya. AZN sebagai penyair mengungkapkannya dalam bentuk puisi, namun hal itu pun menjadi pertanyaan yang memukau. Dalam puisi "Mengapa Selalu Kutulis Sajak", bercerita mengenai keadaan subjek yang merasa dirinya berada pada ruang dilema sebagai manusia yang rindu terhadap Tuhan namun hanya bisa dituangkan dengan sajak.

Mengapa selalu kutulis sajak

Apabila kerinduan tiba-tiba menyerbuku

Mengapa harus sajak, Tuhanku, mengapa harus ia

Yang mampu kupersembahkan kepadaMu

Seandainya ini sebuah tugas

Maka aku terima ia sebagai tugas

Akan kujalani sampai nanti nyawaku terlepas

Seandainya ini sebuah sembahyang

Maka akan kuusir segala bayangan yang datang

Yang selalu mencoba mengaburkanMu

Mengapa selalu sajak yang kutulis itu

Apabila pertanyaan-pertanyaan datang menyerbuku

Selalu sajak, Tuhanku, mengapa selalu ia

Yang mampu kuberondongkan kepadaMu

Atau barangkali karena aku tahu

Engkaulah Penyair itu

Yang begitu mempesonaku
Yang telah membelenggu hidup

dan matiku

Dengan segala keasinganMu

1981

Jika kita cermati dalam sajak tersebut, ada beberapa sajian yang menarik yang disampaikan AZN misalnya; sajak yang menjadi tugas ibadahnya, sajak sebagai sembahyang, dan Tuhan yang dianggap sebagai Penyair. Metafora pada frasa "sajak" menjadi multifungsi dan multi makna. Namun yang lebih menarik di sini, AZN menarik sajak sebagai sembahyang dan dalam tradisi sufi ibadah terhadap Tuhan tidak selalu yang bersifatyang telah diwajibkan seperti shalat. Di sini AZN telah berhasil mengandaikan bahwa sajak belum tentu sebuah tulisan melainkan bentuk pengejawantahan dari bentuk ibadah yang lain.

Selanjutnya frasa "sajak" diejawantahkan seperti surat dan senjata; selalu sajak, Tuahnku, mengapa selalu ia/Yang mampu kuberondongkan kepadaMu. Terbayang oleh kita ketika kerinduan itu meluber, sudah diambang batas, dengan lantang subjek berteriak meneriakan kerinduannya dengan berondongan sajak-sajak. Kemudian frasa "penyair" menjadi bahasa metafora bagi Tuhan, bahwa Tuhan adalah Penyair yang maha Besar.

Berdasarkan pada analisis di atas terlihat bahwa bahasa metafora menjadi bahasa musikalitas yang mengantarkan dunia spiritualitas penyair dalam perjalanan rohaninya. Artinya dalam puisi AZN ini kental dengan daya ucap musikal sebagai bentuk daya ucap bertasawuf.

\subsection{Dimensi Tasawuf Puisi AZN}

Puisi AZN sebagaimana yang sudah dianalis di atas jelas menunjukkan konsep yang berkaitan erat dengan dimensi tasawuf atau perjalanan rohani. Dalam khazanah 
tasawuf, langkah pertama yang harus ditempuh oleh sang pecinta adalah rasa rindu terhadap pencipta. Terang sekali aku lirik dalam puisi AZN selalu mempersembahkan lagunya yang sederhana dengan sungguh-sungguh dengan 'jwa yang melayang' yang merupakan pengejawantahan dari sikap cinta yang serius.

Subjek diposisikan sebagai posisi pengembaraan batin yang cukup lengkap. Keberadaan tubuh menjadi titik penting di sini, tubuh dijadikan personifikasi dari segala pengembaran itu. Sebagai bentuk kerinduan terhadap Tuhan, tubuh memfungsikan dirinya dengan segala dengan nada-nada yang muram. Subjek tubuh mencerna kehidupan yang dialaminya terasa hampa, inilah nada-nada guram/Kasih yang terpendam/ Lirik-lirik lebam/ Kehidupan yang bergoyang-goyang/l.

Bagi seorang pecinta (pengembara) (Lee, 2003: 13) menjelaskan mengenai konsep jalan yang disebut dengan jalan mitis. Baginya jalan mitis adalah sebuah pengembaraan dari dualitas menuju unitas, menuju kemanunggalan praabadi yang tersembunyi dalam kalbu. Bagi kaum sufi, pengembaraan ini adalah sebuah jalinan cinta yang dimulai pada tingkatan jiwa dan diangkat ke dalam kesadaran melalui anugerah atau rahmat Sang Kekasih.

Dari penjelasan di atas, dualitas merupakan kondisi dari kesadaran jiwa yang sedang mengalami pengembaran batin itu. Subjek sadar dirinya sedang mengalami kebimbangan yang luar biasa terhadap situasi lingkungan yang mengelilinginya yang secara farsial sudah tidak dirasakan cocok dengan tubuhnya. Dalam situasi seperti ini, tubuh merasakan proses dualitas yang luar biasa satu sisi tubuh sedang tidak menerima realitas satu sisi tubuh harus menyalurkan ketidakberterimaan realitas tersebut. Sehingga AZN bertutur, "Meskipun kaki selalu goyah/Sadar harus menyanyi/Walau tak mampu meredakan gelisah".

Namun tidak sampai di situ, dualitas tersebut-pada titik penyaluran-harus disampaikan menjadi unitas yang berarti. Menyusuri jalan cinta adalah pengembaraan yang berpusar pada tempat dimana kita selalu menemukan sesuatu yang selalu kita singgahi, namun terselubung oleh batas ilusi, di balik tabir ego dan pikiran. Meskipun dikatakan demikian namun perjalanan tersebut harus ditempuh, AZN lagi-lagi menempuhnya dengan dimensi religiusitas yang tinggi. Subjek lirik dibiarkannya menjadi unitas dengan tensi yang sangat sadar dengan segala kekurangannya, tak berkuasaannya, maka disentuhnya Dia dengan nada yang rendah, Inilah nyanyianku/Lagu yang sederhana/Denting-denting

kerinduan/Dari harpa jiwa yang teramat lengang.

Setiap manusia, siapa pun pasti mengalami ruang batin yang berbedabeda. Ruang batin itu diekpresikan tentu dengan kreativitas yang berbeda pula, pada AZN pengekspresian pengolahan ruang batin itu dia tanyakan lewat puisinya yang menawan. Sebagaimana yang dilakukan oleh para penyair sufi seperti Rumi atau Attar. Kalau Rumi atau Attar ruang ekspresinya dinyatakan langsung lewat puisinya tentang kerinduan-kerinduan itu namun AZN ada ruang ekspresi yang terbalik. AZN justru menanyakannya kenapa dia menulis selalu menulis puisi, kenapa harus menulis puisi untuk mengantar kerinduan terhadap religiusitasnya terhadap Tuhan.

Mengapa selalu kutulis sajak

Apabila kerinduan tiba-tiba menyerbuku 
Mengapa harus sajak, Tuhanku, mengapa harus ia

Yang mampu kupersembahkan kepadaMu

Atau barangkali karena aku tahu

Engkaulah Penyair itu

Yang begitu mempesonaku

Yang telah membelenggu hidup

dan matiku

Dengan segala keasinganMu

1981

Menarik sekali ruang ekspresi AZN pada puisi ini, secara intensitas sangat berbeda dengan ruang ekspresi yang dilakukan oleh dimensi sufi Timur Tengah. AZN memosisikan dirinya bahwa dia adalah manusia yang tidak bisa secara fisik melakukan semacam ritual dalam bentuk ritual keagamaan, seperti sembahyang misalnya. Dia justru lebih memilih sajak adalah ruang ritual ibadahnya tersebut. Subjek tidak tahu kenapa hal itu terjadi, sampaisampai sajak disanding sebagai 'sebuah sembahyang'. Selanjutnya, AZN menjadikan sajak adalah suatu tugas yang harus terus menerus ditulis apalagi ketika kerinduan terhadap Tuhan sedang merasuki tubuhnya. Maka sajak tak terbendung untuk terus ditulis sampai pada titik penghabisan.

Dari peristiwa yang ada di dalam puisi di atas, secara eksplisit seperti terasa kontradiktif dengan kewajiban ritual selayaknya manusia beribadah. Yakni shalat, dan sebagainya. Namun AZN memilihnya dengan puisi. Dalam ranah tasawuf, proses yang dimaksud dalam penjelasan di atas merupakan sutu tingkatan atau maqam tertentu dalam perkembangan dimensi sufistiknya. Jika dilihat dari ranah itu, penjelasan itu mengacu pada apa yang dimaksud dengan takhalli yakni tahapan awal bagi setiap manusia unutk meraih jalan sufi. Pada tahapan ini, sufi harus lebih memilih untuk tidak mencintai dunia. Apapun alasannyabaik dalam sisi materi atau nonmateri-konsep keduniawian itu tidak terus stagnan dan menjadi patokan utama yang harus ditempuh oleh setiap pecinta. Melainkan adalah sesuatu yang memang harus betul-betul ditinggalkan-hidup selalu dalam kesederhanaan.

Kecenderungan pada fase takhalli jika ditinjau dari sudut pandang sosial merupakan sikap atau rasa keterasingan seseorang terhadap benturan nilai-nilai yang dirasa telah mengganggu dengan kebenaran yang mutlak. Maka secara sadar subjek akan terus melantunkan kerinduankerinduannya terhadap sang pencipta. Bahkan secara tak sadar diri subjek pun akan mempertanyakan siapa dirinya sebenarnya. Pada situasi ini, kesunyian terus menyelimuti individualitasnya secara menyeluruh.

Sebagai fase dari takhalli bentuk-bentuk mempertanyakan diri yang sebenarnya sangat penting, bukan berarti kemurungan atau kerendahdirian melainkan menyadari kekuatan dan kehidupan spiritualnya artinya dia sedang mengakui kekuatan dirinya. Ajaran tasawuf mengenai kekuatan diri ini adalah jalan kepasrahan. Namun, kepasrahan ini tidaklah pasif, tetapi merupakan jalinan dinamis sumber energi batiniah untuk mengangkat dan mengubah hawa nafsu, ego, dan syahwat. Kendali kekuatan purba dalam diri manusia digunakan untuk-Nya semata, bukan untuk hasrat ego (Lee, 2003: 62).

\section{Simpulan}

Bertolak dari hasil analisis mengenai perkembangan dimensi tasawuf dalam puisi AZN periode awal diperoleh simpulan bahwa puisi AZN secara struktur gaya bahasa, yang dalam hal ini relasi metafor terhadap tanda- 
tanda keTuhanan yang berkembang dalam puisi-puisinya sangat beragam. Pada periode awal kepenulisannya melakukan eksplorasi bahasa yang masih terpengaruh pada nuansa syairsyair sufi Timur Tengah dengan mengeksplorasi pada kekuatan metafora musik yang merujuk pada konsep tasawuf yang menempuh 'jalan sunyi.

$$
\text { Selanjutnya puisi AZN }
$$

menyajikan celah-celah kehidupan manusia yang cenderung selalu mengembara untuk menempuh jalan kehidupannya. Fase-fase yang dilakukan AZN lewat puisinya tersebut merupakan gambaran dari fase 'jalan sunyi' yang dikembangkan dalam konsep tradisi tasawuf. Pengembaran itu oleh AZN disajikan dalam bentuk pemahaman terhadap sistem agama, yang mengarah pada konsep beribadah terhadap sang Khalik yang disebut dengan dimensi takhalli.

\section{Daftar Pustaka}

Abrams, M.H. 1981. A Glossary of Literary Term, New York: Holt, Rinehart and Wiston.

Braginsky, V.I. 1993. Tasawuf dan Sastera Melayu Kajian dan Teksteks, Jakarta: Seri Publikasi Bersama Pusat Pembinaan dan Pengembangan BahasaUniversitas Leiden.

Isa, Syaikh Abdul Qadir. 2011. Hakekat Tasawuf. Terj. Khairul Amru Harahap dan Afrizal Lubis. Jakarta: Qisthi Press.

Lee, Llewellyn Vaughan. 2003. Lingkaran Cinta Sufi. Terj. Eva Y. Nukman dan Sofie Dewayani. Bandung: Pustaka Hidayah.

Lewisohn, Leonard. et all. 2002. Warisan Sufi; Sufisme Persia Klasik dari Permulaan Hingga Rumi (700-1300) Buku Pertama.
Terj. Gafna Raizha Wahtudi. Yogyakarta: Pustaka Sufi.

Mangunwijaya, Y.B. 1988. Sastra dan Religiositas. Yogyakarta: Penerbit Kanisius

Noor, Acep Zamzam. 1982. Tamparlah Mukaku. Bandung: C.V. Adi Agung. 1986. Aku Kini Doa. Bandung: Kelompok Sepuluh. 1996. Di Luar Kata. Jakarta: Pustaka Firdaus.

Rosidi, Ajip. 1976. Ikhtisar Sejarah Sastra Indonesia, Bandung: Penerbit Binacipta.

Schimmel, Annemarie. 2005. Akulah Angin Engkaulah Api Hidup dan Karya Jalaluddin Rumi. Bandung: Mizan.

2000. Dimensi Mistik

Dalam Islam. Jakarta: Pustaka Firdaus.

Setiadi, Tia. 2009. Dari Zaman Citra ke Metafiksi Bunga Rampai Telaah Sastra DKJ. Jakarta: KPG dan DKJ.

W.M., Abdul Hadi. 1985. Rumi Sufi dan Penyair. Bandung: Penerbit Pustaka.

(tanpa tahun). Sastra Sufi Melayu dan Gemanya dalam Sastra Modern Indonesia. Belum Diterbitkan. 
Jurnal al-Tsaqafa Volume 13, No. 01, Januari 2016

Halaman ini sengaja dikosongkan 